\title{
The Role of Student's Parent in Shaping Home Learning Environment (HLE) for Early Childhood
}

\author{
Pramesti Indah Kumalasari $^{\varpi_{1}}$, Sugito $^{2}$ \\ Pendidikan Anak Usia Dini, Universitas Negeri Yogyakarta \\ DOI: $\underline{10.31004 / \text { obsesi.v5i2.881 }}$
}

\begin{abstract}
This study aims to determine the role of parents in forming a Home Learning Environment (HLE) for early childhood in Trucuk, Klaten. This study used a qualitative approach with descriptive methods and was carried out by purposive sampling. The research subjects were 5 parents who have children aged 3-4 years. Data collection techniques used were observation, interviews, and documentation techniques. Data analysis used was data collection, data reduction, data presentation, and drawing conclusions. Based on the research that has been done, the role of parents in shaping HLE is seen when parents introduce new learning materials into the home through activities (playing, chatting and reading), preparing HLE according to children's needs and interests, offering various learning opportunities and providing learning experiences that are fun. With the role of parents in shaping HLE, it can be an early intervention program and direct children's activities to be more useful in reaching the next stage of development.
\end{abstract}

Keywords: parents; home learning environment; childhood

\begin{abstract}
Abstrak
Penelitian ini bertujuan untuk mengetahui peran orang tua dalam membentuk Home Learning Environment (HLE) anak usia dini di Trucuk, Klaten. Penelitian ini menggunakan pendekatan kualitatif dengan metode deskriptif dan dilakukan dengan cara purposive sampling. Subjek penelitian berjumlah 5 orang tua yang memiliki anak berusia 3-4 tahun. Teknik pengumpulan data yang digunakan adalah teknik observasi, wawancara, dan dokumentasi. Analisis data yang digunakan adalah pengumpulan data, reduksi data, penyajian data, dan penarikan kesimpulan. Hasil penelitian menunjukkan bahwa lingkungan belajar di rumah merupakan tempat di rumah yang membantu anak dalam belajar berbagai hal. Berdasarkan penelitian yang sudah dilakukan, peran orang tua dalam membentuk HLE terlihat saat orangtua memperkenalkan materi pembelajaran baru ke dalam rumah melalui kegiatan (bermain, mengobrol dan membaca), menyiapkan HLE sesuai dengan kebutuhan dan minat anak, menawarkan berbagai kesempatan belajar dan memberikan pengalaman belajar yang menyenangkan. Dengan adanya peran orangtua dalam membentuk HLE dapat menjadi program intervensi dini dan mengarahkan aktivitas anak agar lebih bermanfaat dalam mencapai tahap perkembangan selanjutnya.
\end{abstract}

Kata kunci: orang tua; lingkungan belajar rumah; anak usia dini

Copyright (c) 2020 Pramesti Indah Kumalasari, Sugito

$\triangle$ Corresponding author :

Email Address : pramestiindah.2019@student.uny.ac.id (Yogyakarta, Indonesia)

Received 6 November 2020, Accepted 30 November 2020, Published 5 December 2020 


\section{INTRODUCTION}

The educational environment is an environment that can support the educational process or a situation that can be used for ongoing educational activities (Arigusman, 2017; Nielsen, 2015; Romo, 2015). It includes the family, school, and community environment. It is one of the important components that must be considered in early childhood education. One crucial element to achieve educational goals is the creation of a pleasant and comfortable environment where learning is carried out. A relaxed environment that supports the implementation of education is hugely needed and also influences the achievement of educational goals.

Ecological Theory views that human development in influenced by the environmental context. Interactions that occur between children and the surrounding environment can significantly affect the children's growth and development process. According to Ecological Theory, children develop in many layers of context (i.e., society, school and family) and distal contextual layers (i.e., policies and culture government) that interact with each another to influence early childhood (Murphy, 2020). In a micro system, there are many direct interactions with social agents, namely parents, friends and teachers. This environment greatly affects individual development, especially in early childhood. The family subsystem, especially parents, in the micro system is considered the most important socialization agent in the life of a child so that the family has a big influence in shaping the character of early childhood.

In HLE practice, parents represent the microsystem of children's development regulation. There is a further influence on learning because children are at the center of a multidimensional system (Niklas, Cohrssen, et al., 2016c). Elements of this system include the proximal impact of HLE, childcare arrangements, and features of the ecosystem as family and community support services. Micro system elements have an impact on childcare, and other ecosystem features in families and communities. Macro system influence further encompasses migrant status and cultural values. Elements of the proximal system mediate components of a distal macro system. HLE exist in a micro system, which seeks small-scale local interventions to enhance children's preschool learning experiences.

A learning environment is place where adults become sustainable learners and give children try new things, space to explore and make learning a fun. HLE is the whole that is in the home environment and includes family interactions. Through this environment, children learn to investigate the world and know for learning in terms of attitudes and behavior through family contexts. Having a positive learning environment can foster skills and encourage active learning for early childhood.

Home Learning Environment (HLE) has long and short term effects in early childhood development. It plays an essential role in preparing children before entering formal school. Before entering school, one is known as a good predictor for children of literacy and numeracy (Niklas, Cohrssen, et al., 2016a). HLE is also linked to early childhood academic achievement through cumulative skill acquisition; positive HLE will improve the basic skills of early childhood which are the basis for further development through school education (Bojczyk et al., 2018). Toth et al. (2020) found that home literacy environments explain differences in the predecessors of reading achievements such as vocabulary and phonological awareness. The availability of positive HLE can support the development and performance of children in various phases of education.

The concept of HLE consists of various aspects that support early childhood development at home, and given to the mathematics and literacy in their family (see Niklas, Cohrssen, et al., 2016c, 2016a, 2016b; Niklas, Nguyen, et al., 2016; Schmiedeler et al., 2014). The frequency of children's reading habits and games in a mathematical done by parents must be considered. Likewise, the attitudes, the support of parents in children must be regarded as well and the expectations of parents. This perspective reminds of the importance of HLE for in early childhood development and also as a basis for supporting 
further education (Lehrl, Evangelou, et al., 2020). Hall et al., (2019) found that there is a positive relationship between children and HLE in improving the quality of learning related to children's behavior disorders. High-quality HLE in the early years encourages more subsequent developmental and educational outcomes. The effects of HLE have an impact on early childhood achievement in the early years of education. It has consequences in the first years found to be higher than in other school phases. However, some studies take a broader view of it and investigate the learning opportunities offered by parents to children at home, reading and writing habits, and also related to children's achievement. Regarding learning opportunities provided for children, it is assumed that learning occurs through interactions with certain learning activities between parents and children that are expected to directly and indirectly on students' achievement (Dimosthenous et al., 2020).

Several studies have shown that HLE is closely related to cognitive outcomes and predict numeracy and literacy in early childhood (Toth et al., 2020). Children's learning and role of family can positively influence children's cognitive development, academic achievement and school performance (Alves et al., 2017). The Home Learning Environment (HLE) experienced by children influences learning outcomes and enriches the context to improve learning, development, and child welfare. Parents, as the first educators, contribute learning outcomes with HLE, development, and overall child welfare (Niklas, Cohrssen, et al., 2016b, 2016c, 2016a). Positive parental relationships, interactions, and collaboration are seen as necessary in encouraging children's interactions and helping parents stimulate child development with HLE (Lehrl, Evangelou, et al., 2020). It has the potential to shape attitudes towards children's learning, children's readiness for school, and academic achievement in the future (Sammons et al., 2015).

This finding is supported by other studies that show that the HLE given to early childhood has become a new interest to see various kinds of child development. Family settings, especially the quality of the learning environment at home, have proven to be important for children's development. Many studies assess the learning environment at home as affecting various educational outcomes (e.g., early arithmetic, early literacy, language development and numeracy skills (Kluczniok, 2017), children's vocabulary (Linberg et al., 2020), reading (Zhang et al., 2020). Apart from being a predictor of cognitive development, HLE is also an important predictor of early childhood social development. The results of measurements in each HLE school predicts the literacy development and to reading ability in primary schools. The learning environment at home is also a crucial means to improve children's mathematical competence and reading through two channels, namely initial capability and then HLE (Lehrl, Ebert, et al., 2020; Lehrl, Evangelou, et al., 2020). Further evidence of the importance of it for children's development comes from direct intervention studies. The meta-analysis focusing on family literacy programs in a family context reveals the small to medium effects of such programs on children's linguistic competence (Sénéchal \& Lefevre, 2014). There are also some shreds of evidence that homebased interventions can be successful in increasing children's numeracy competencies and even children's general cognitive abilities (Niklas, Cohrssen, et al., 2016a).

Children usually spend most of their time with their family in the early years. Parents have a significant influence on early childhood development because they are first to follow the development of a child from birth. In studies assessing the early impact of early childhood education and care programs (ECEC) (Alves et al., 2017) it is said that parents is the first factor as a strong predictor for developmental outcomes. Most studies examine the long-term and short-term effects on early childhood development, so there are still few studies examining the role of parents in creating learning environments at home. Parents play an important role in guiding and accompanying children in their children's daily lives. Parents have an obligation to create a conductive learning environment so that it can stimulate children's potential and intelligence from an early age. The role of parents is equally important in the educational process. It is at this point that parents are obliged to 
prepare a good learning environment for their children. The aim is to provide and shape a home learning environment while supporting early childhood in the learning process. Therefore, researchers want to examine their role in creating HLE as the first learning environment that can determine children's success later.

\section{METHODS}

This research uses a descriptive qualitative approach. Qualitative research is an approach to understand certain social situations, events, roles, groups, or interactions (e.g., Anum \& Apriyanto, 2019; Apriyanto \& Anum, 2018; Creswell, 2007; Hatch, 2002; Moen \& Middelthon, 2015; Santoso \& Apriyanto, 2020). Most of the research is an investigative process where researchers gradually understand social phenomena by comparing, replicating, cataloging, and classifying research objects (M. B. Miles \& Huberman, 1994). Holloway \& Wheeler (2010) suggest that qualitative research requires immersion in the daily life of the settings chosen for study researchers enter the world of informants and through continuous interaction, seeking informant perspectives and meanings. The research was done in Trucuk District, Klaten Regency.

Research subjects or respondents in qualitative research are often referred to as informants. The research subjects were taken by purposive sampling technique. Research subjects were Mrs. Hesti who have 3-year-old children, Mrs. Ayu who have 3-year-old children, Mrs. Putri who have 3-year-old children, Mrs. Danik who have 4-year-old children, and Mrs. Endang who have 4-year-old children. HLE is a home environment provided by parents before children enter a formal school where early childhood is in the age range of 0-6 years. With the above understanding, the selection of research subjects focuses on parents who have children under six years old (Williamson, 2018).

The data collection steps in this study include setting boundaries for studies that begin with sampling, gathering information through observation and interview, documentation, and establishing protocols for recording data. Identification of locations or individuals has chosen deliberately for the proposed study (Flick, 2014). Data collection is done in three ways, namely, observation, interviews, and documentation. This study uses open observation because the researcher asks general questions from the participants that allow participants to give their views freely. This involves unstructured, generally open, and few questions intended to gain the views and opinions of the participants.

\section{Table 1. Instrument Grid}

\begin{tabular}{|c|c|c|c|c|}
\hline No & Focus & Aspect & Technique & Informant \\
\hline 1 & $\begin{array}{c}\text { The first step } \\
\text { taken by parents } \\
\text { before creating } \\
\text { HLE }\end{array}$ & $\begin{array}{l}\text { Parental understanding of HLE } \\
\text { Parental knowledge before } \\
\text { administration of HLE } \\
\text { Parental involvement in the } \\
\text { intervention program }\end{array}$ & $\begin{array}{l}\text { Interview and } \\
\text { observation } \\
\text { Interview and } \\
\text { observation } \\
\text { Interview and } \\
\text { observation }\end{array}$ & Parents \\
\hline 2 & $\begin{array}{l}\text { Form of HLE } \\
\text { activities }\end{array}$ & $\begin{array}{c}\text { Activities provided by parents in } \\
\text { creating HLE }\end{array}$ & $\begin{array}{l}\text { Interview and } \\
\text { observation }\end{array}$ & Parents \\
\hline 3 & $\begin{array}{l}\text { Supporting } \\
\text { factors in } \\
\text { creating HLE }\end{array}$ & $\begin{array}{l}\text { The things that parents do in } \\
\text { creating HLE }\end{array}$ & $\begin{array}{l}\text { Interview and } \\
\text { observation }\end{array}$ & Parents \\
\hline 4 & $\begin{array}{l}\text { Constraints in } \\
\text { creating HLE }\end{array}$ & $\begin{array}{c}\text { Parental education and economic } \\
\text { background }\end{array}$ & $\begin{array}{l}\text { Interview and } \\
\text { documentation }\end{array}$ & Parents \\
\hline
\end{tabular}


Then, the researchers arranged a visit and interview schedule with the children's parents. The plan is determined when researchers ask permission to come directly to the house. Researchers make an agreement with the parents of children regarding the time that can be provided for interviews and observations. From the results of visits with parents, the researchers compiled a grid of instruments before conducting interviews with parents. The instrument grid is arranged based on data collection from various theories and references. The lattice of the instrument includes the focus of the research, the aspects to be studied, the techniques used for the research and the informants. With this grid, it is hoped that the interviews will not go out of the way that already exists. Interviews were conducted directly with parents to find out: (1) the initial steps taken by parents in creating HLE, (2) the form of HLE activities given by parents, (3) supporting factors in creating HLE, (4) Constraints in creating HLE. Documentation is done by collecting secondary data in the form of reports, guidelines, and other documents relating to the problem to be examined. In qualitative research, researchers become the main instrument in addition to the use of interview and observation guidelines. Therefore, this study aims to determine the role of parents in creating HLE.

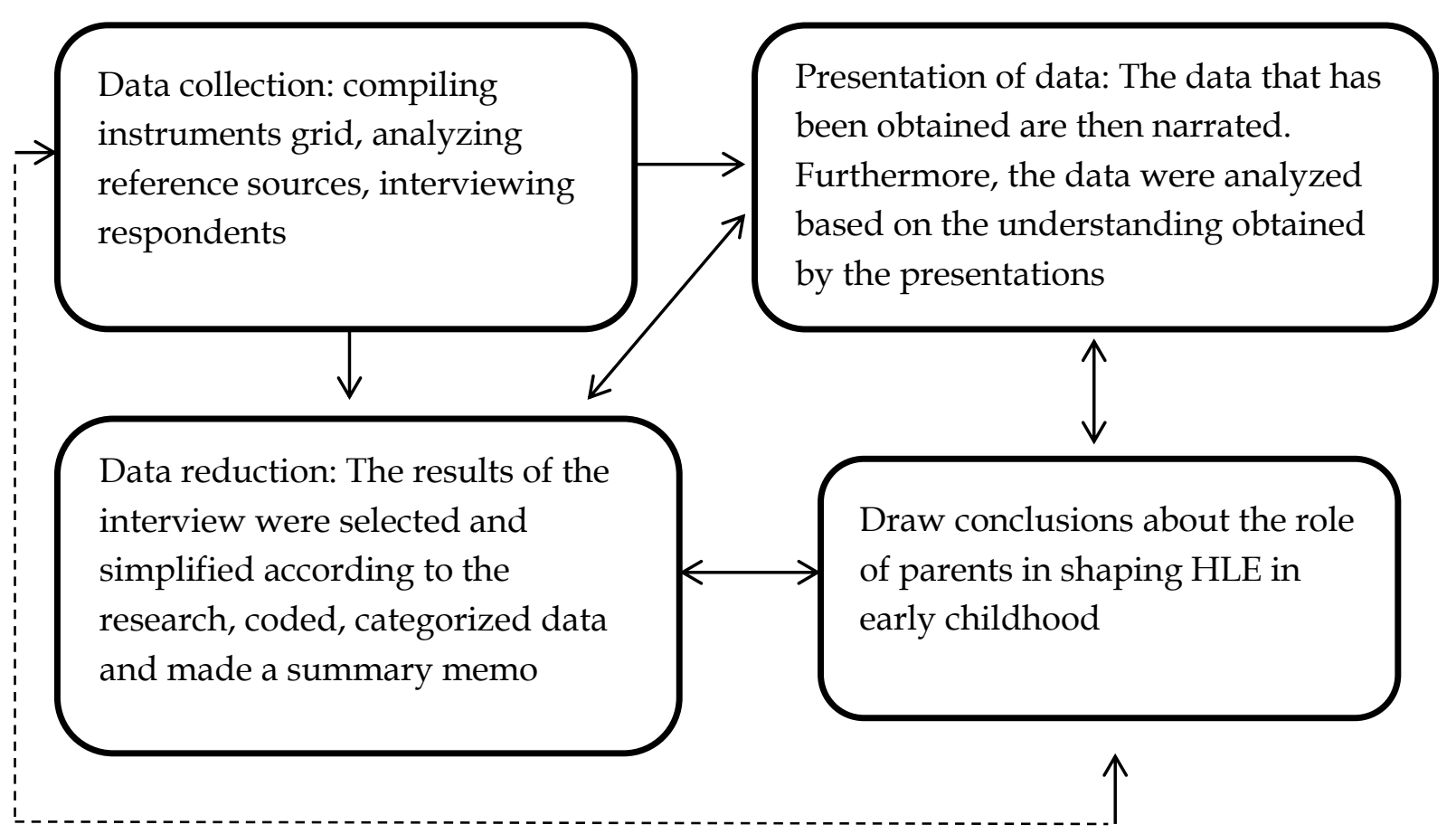

Figure 1. Miles and Huberman's Research Schematic Model

The process of analyzing data is qualitatively interactive, using the Miles and Huberman analysis model (Miles et al., 2014; Miles \& Huberman, 1994). This analysis consists of four components that run simultaneously and interact with each other, namely data collection, data reduction, data presentation, and concluding. Miles and Huberman's model has four stages in the data analysis process. The first step is data collection. Researchers make instrument grids, analyze reference sources and interview respondents. The second step is data reduction, at this stage the researcher selects and simplifies the results of the interview according to the research. The data were coded, categorized and a summary memo was generated. The third step is presenting the data. The data that has been obtained are then narrated. Furthermore, the data were analyzed based on the understanding obtained from the presentation. The fourth step is drawing conclusions about the role of parents in shaping HLE in early childhood. 


\section{RESULT AND DISCUSSION}

\section{Parental understanding of HLE}

The results of the interviews were conducted with Ayu's Family. Ayu's family has a 3 -year-old child and has not been at school. The child is the second child of two siblings. The father with Bachelor graduate works in a private company, while the mother with Diploma. Interviews conducted with Mrs. Ayu, are related to the form of understanding of HLE (home learning environment)

Interviewer : What do you think is the meaning of the learning environment at home?

Mrs. Ayu : The learning environment at home is the environment that surrounds us and covers all the conditions that exist in the place of the learning process. It can affect children's development, teaching and learning process, children's attitudes, and behavior. One can be an opportunity for children to learn many things related to current environmental issues. So, the home learning environment is everything in the house that can affect the process and results of children's learning. By this environment, we as parents can build interactions, communication, and direct the activities of children to be more useful and reach the stages of development.

The results of interviews were conducted with Hesti's mother's family. They have a 3 year old child and their first child. Hesti's family currently lives with Hesti's in-laws, so there are grandparents, Hesti and husband. Mrs. Hesti and her husband are high school graduates; The husband works near the house, and Hesti's mother is a housewife. Related to the form of understanding HLE (learning environment at home) which was conveyed by Mrs. Hesti that: Interviewer: What do you think is the meaning of the learning environment at home?

HS's mother: The learning environment at home is a place that is at home that helps children learn a variety of things. Shortly, it is anything that is around the house that supports children's learning. Everything in the house can be a source of learning for children. Giving knowledge can be done by anyone, for example, with grandparents.

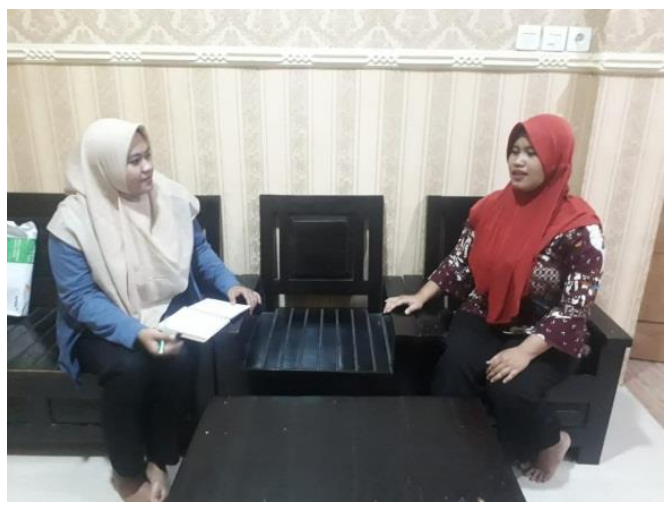

Figure 1. Interview with Mrs. Ayu

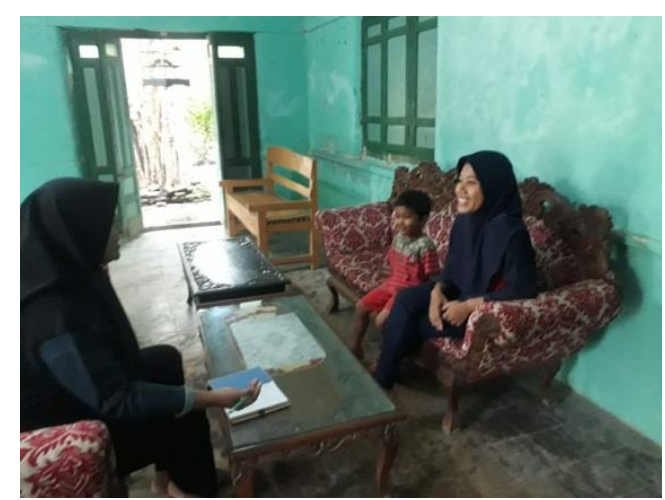

Figure 2. Interview with Mrs. Hesti

The home learning environment is a learning environment for children available at home and provided to support the fulfillment of children's learning. Parents as the primary caregiver in providing learning must understand the needs of children from an early age. Learning can be done anywhere, but early childhood is a child in the age range of 0-6 years in which all the fulfillment of development, growth, and learning is done at home by parents. The environment becomes a place to interact with each other, a safe place to grow and learn for young children. The environment is very important in the early years of the child. The environment is often referred to as the third teacher for children after the role of parent and teacher. The learning environment is the space and context in which children grow, play, and learn at the same time. The learning environment at home is an environment that children need at all times to interact with the family both inside and outside the home. 
DOI: 10.31004/obsesi.vxix.xxx

Each person's HLE understanding differs depending on the perspective and knowledge he has. Parents who have broader knowledge tend to understand the meaning of HLE. Some parents also emphasize that what is given at home is an important thing which can later affect the lives of children. Before providing a learning environment for children, parents need to understand a good home learning environment for children. In addition, parents must ensure the purpose of providing learning and when the right time to share learning at home. With a strong learning environment, this will encourage children to collaborate with families to carry out various activities together. Parental involvement in this learning can indirectly support, expand, and deepen children's knowledge and understanding.

\section{The early steps done by parents before creating HLE}

Interviewer : What are the initial steps parents take before creating HLE?

Mrs. Putri : Before taking further steps in creating HLE, parents need to understand the extent of their ability to provide or create it, so this will affect the provision of it. Parents need to make preparations and know that each child has different ages and interests. So what is presented in it must be adjusted to the age and interests of the child.

Interviewer : What are the early steps parents take before creating HLE?

Mrs. Danik : In addition to preparing children's needs in HLE, parental participation in providing activity programs is needed, and the amount of time given can help children feel that what the child is doing is getting more attention from both parents. Both parents also need to build emotional warmth so that the activities given can be conveyed and well received by children.

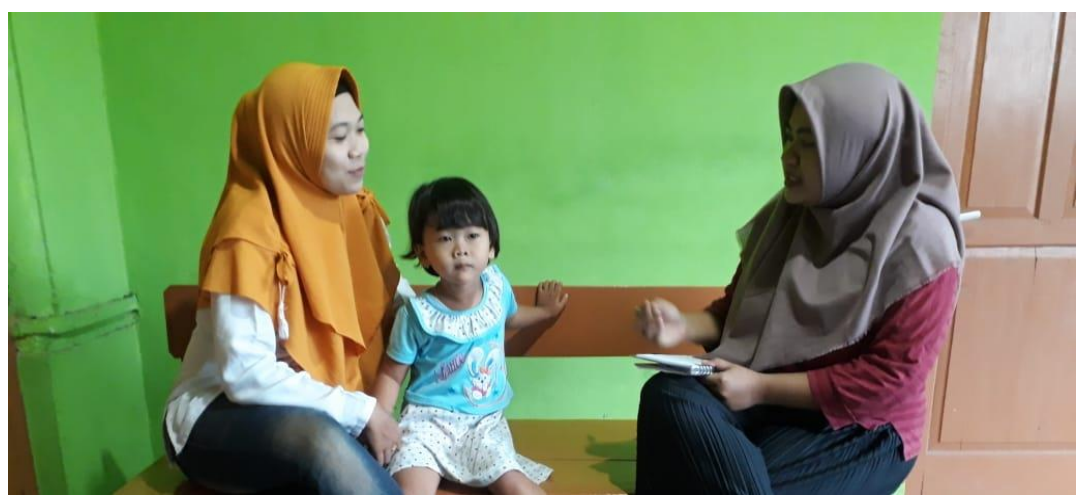

Figure 3. Interview with Mrs. Putri

Before giving HLE to children, parents need to know what needs must be met in learning. Knowledge is one of the important things that parents must-have. Every child has different needs and interests, so parents must find out from an early age. Parents need to prepare in advance what is the target of learning because this will determine the activities that must be given later. A comfortable environment can provide a focus on learning and make children work well because this is one of the basics of children's learning. The learning environment at home begins with the provision of spring and stimulation provided for the child's early education and can help children's learning activities.

Every child cannot reach the same level, but parents must believe that every child will get the best achievement in their abilities because of the right encouragement and support from parents. The provision of learning and education begins from the family environment. Learning in the early years that parents do is a golden opportunity for young children to develop self-confidence, children's skills, and help achieve the potential to support children's education going forward. 


\section{Activities given by parents in HLE}

Interviewer : What activities did you give during HLE?

Mrs. Ayu : 3 years old child likes to play, so the activities provided in the form of daily activities are packaged in the style of play. In her spare time, Mrs. Ayu also invites her children to chat and read stories from story books and introduce animals to children. Apart from learning, these activities are an opportunities to learn in a family environment.

Interviewer : What activities did you give during HLE?

Mrs. Hesti : Learning experiences can be obtained through singing. Mother must like to teach singing to children. Parents can encourage this learning so that it is considered a component of the learning environment at home in the child's early years.

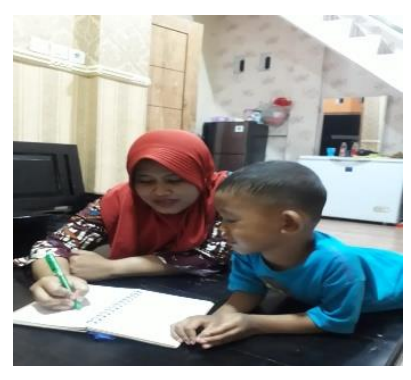

Figure 4. Mrs. Ayu introduces animals through a picture

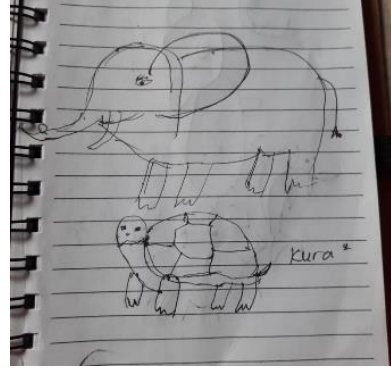

Figure 5. The animals introduced by Mrs. Ayu were elephants and turtles

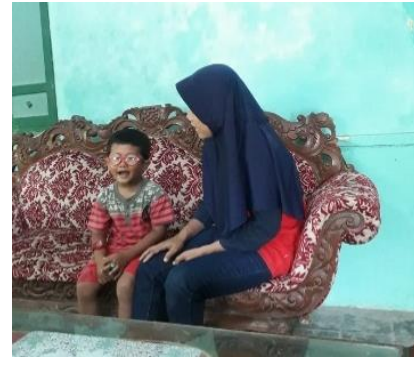

Figure 6. Mrs. Hesti must teach children a song

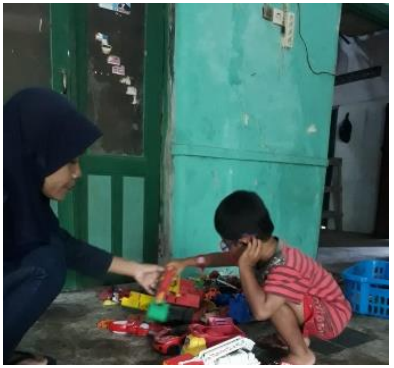

Figure 7. Mrs. Hesti must invite children to play while introducing colors

An effective learning environment can encourage learning for early childhood. The available environment offers a variety of learning opportunities that involve playing, movement, sensory use, and creativity. The human brain records various experiences throughout a child's life. Children can learn various things in certain environments with different people. The brain in a child applies information that has been previously stored in the past and processes newer experiences. At home, parents can provide experiences from play activities and provide a fun learning experience for children. Simple things that parents do can affect a child's development and provide positive results later in life. Warm parenting can create a good bond between parent and child.

Early childhood is a child who likes to play so that everything related to children is directed to play while learning. Play can support the growth and development of children, and make children have the ability to control their environment. By playing also children will get new things so they can explore and practice everyday life. The provision of stimulation to children must be adjusted to the child's growth and development. Daily activities can be used as new activities in HLE. Simple things in daily activities have many benefits for early childhood learning.

\section{Things that support parents in creating HLE}

Interviewer : In your opinion, what things can support parents in creating HLE?

Mrs. Danik : For activities to run smoothly, supporting factors come from the child. Child's participation in activities is essential, so the events can also run well. The parents must be smart to invite their child to participate in the activities provided. Motivation at the beginning is also recommended because if parents provide motivation, this will make the child more confident. The actions or games that are given must also be exciting for him/ her and adapted to the abilities.

Interviewer : your opinion, what things can support parents in creating HLE? 
Mrs. Endang : According to Endang mother, the amount of time given by parents is very important in supporting children. Although busy, parents need to give their best time so that parents can directly monitor the children's development.

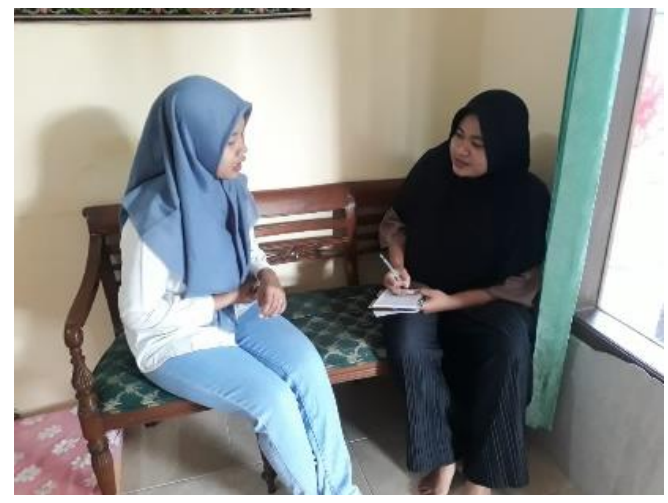

Figure 8. Interview with Mrs. Danik

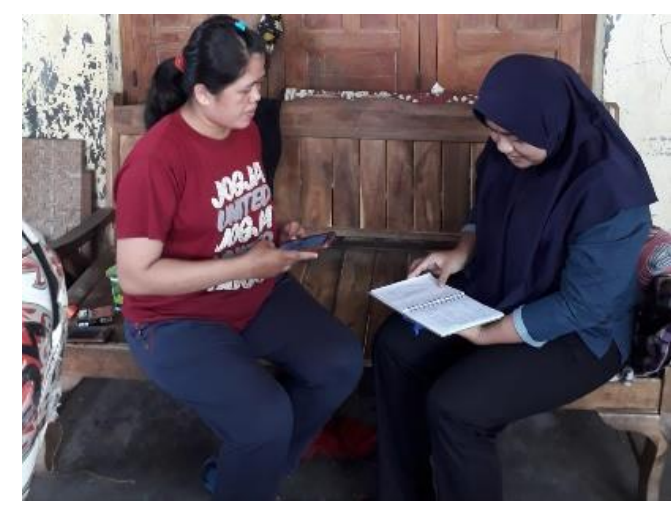

Figure 9. Interview with Mrs. Endang

HLE activities given by parents will not run smoothly if the child, as the subject of learning, does not participate directly in the learning process for that the presence of children is considered important. Each child has different stages of age, so this can determine the extent to which the child can concentrate and carry out activities in play. Parents need to motivate children so that children want and want to do the activities provided. The activities that are given must certainly be fun and interesting for children. That way, children will feel attracted and can indirectly help children hone the constraints right from the child's golden age.

In addition to children's participation and motivation, the amount of time given by parents is also important in HLE. Every parent has their respective activities in working, managing the house or doing other activities. But with this activity, parents need to pay attention and give time to children too. Growth and development of children need to be considered because with this, parents can find out the strengths and weaknesses of children so they can provide appropriate stimulation. The little attention given by parents means a lot to children in supporting the HLE learning process.

\section{Obstacles faced by parents in creating HLE}

Interviewer : In your opinion, what are the obstacles to providing HLE?

Mrs. Endang : There are many things that Mrs. Endang must sharpen; she still needs to learn in adding knowledge in creating HLE. Mrs. Endang has two children, where the mother already has experience in providing learning at home. The husband is busy at work, only has less time. So on Saturday and Sunday, it becomes a special time for children.

Interviewer : In your opinion, what are the obstacles to providing HLE?

Mrs. Putri : Mrs. Putri is in low economic condition and lack of the participation of grandparents in the provision of HLE. Also, Mrs. Putri experiences firstly in becoming a mother, so there is still a lot to learn in creating positive HLE for children. Her education level does not make her discouraged from learning from the internet.

Parental knowledge in providing HLE is needed. Every parent has different knowledge in giving HLE. Parents who have extensive knowledge tend to do variations in the administration of HLE. In addition, parents' experience also influences the provision of HLE. This experience can be used as learning in the future for the second child, and so on. Parents who have experience in the provision of HLE will know-how and tips for early childhood. In addition to the knowledge and experience that parents have, parents' economic conditions can also influence the creation of HLE. This condition can inhibit the administration of HLE to children where the administration of HLE is not optimal. These 
conditions will determine the learning process provided by the child. The level of education a parent has is usually also related to the knowledge parents have. Parents who have a high education tend to want to provide good and maximum learning, but do not rule out the possibility of parents of low educational level and low economy also want to provide good HLE for children. Parents who have low levels of education can learn through the internet to add insight so that HLE can be given to the maximum as well. Results of research, results of research, results of research, results of research, results of research, results of research, results of research.

\section{Discussion}

The learning environment at home is an environment that surrounds the parent-child and covers all the conditions that exist in the learning process. Based on the results of research, the learning environment at home is a place at home that helps children learn various things. In short, everything in the home supports children's learning. Everything in the house can be a source of learning for children. Giving knowledge can be done by anyone. With this environment, parents can build interaction, communication, and direct children's activities to be more useful and reach developmental stages. HLE has been started before early childhood start entering formal education, where a child usually spends a lot of time in the early years to interact with actively or his parents (Niklas, Cohrssen, et al., 2016c, 2016a, 2016b). In line with that Kluczniok (2017); Lehrl, Ebert, et al., (2020) and Lehrl, Evangelou, et al., (2020) which explains that HLE is everything that is in the home environment related to learning activities and certain individuals in receiving the learning given. HLE includes something that is in the context of the home covering a variety of learning activities in academic development and early childhood education. (Lehrl, Evangelou, et al., 2020).

HLE is an important tool that parents use to teach early childhood knowledge and skills to be able to successfully adapt to the society, environment, and culture (Sammons et al., 2015). The concept HLE includes activities in the family that provide intellectual stimulation for children, such as visiting a library or reading a book (Schmiedeler et al., 2014). Besides, it also consists of all aspects of the home that support the development and focuses on children's mathematical abilities and literacy in their family context (Kluczniok, 2017). These characteristics indicate the capacity of the home learning environment in the early years to promote early numeracy skills and literacy (Soto-Calvo et al., 2020). Parents need to have competence in creating learning opportunities and trusting abilities in teaching children them (Bojczyk et al., 2018).

Children with high-quality environmental characteristics during their first three years must be better than children who have early experience. HLE contains several important features, including the materials literacy, activities in which parent and children involvement, the quality of parent-children interaction that available for children's learning. The provision of this feature is due to the characteristics of the participating families, parents who participate directly and actively in children's activities can stimulate early childhood cognitive abilities (Biedinger, 2011). However, not all parents know how to best support their early childhood in offering specific high-quality HLE, as explained by Skwarchuk et al., (2014). Parents' knowledge can help to determine education in the family where the program is tailored to the characteristics of each family.

Before taking further steps in creating HLE, parents need to understand the extent of the child's ability to provide or create HLE, so this will affect its provision. Parents need to learn about preschool behavior that is appropriate for the child's age, discipline strategies, relevant games, materials, and activity readiness. Parents as primary caregivers must have the motivation, skills, and knowledge to involve opportunities for learning at home long before they arrive at formal school. Parents must act as the first teacher and need to know the skills required by their children to succeed in school. Bojczyk et al. (2018) show that maternal self-efficacy is related to the perception of children's readiness and to better control of the 
home learning environment for early childhood. Increasing maternal effectiveness will result in a more significant home learning environment, literacy environment and ensure that early childhood is ready for school academic activities. This also shows that a mother feels her ability to teach early childhood. The HLE that a parent provides depends on the perception of what he is ready to learn and what he is ready to teach in early childhood.

Several studies have shown that parental involvement in early intervention programs can positively influence parent-child interactions. In addition, it can also increase parental understanding in stimulating children's learning skills from an early age. For example, it can increase the active role of parents in facilitating children's learning processes, such as introducing new learning materials into the home (Kluczniok, 2017; Biedinger, 2011) Parents can participate in children's play activities, organize certain activities, observe, participate and support children's learning or pay attention to children's education (Niklas, Cohrssen, et al., 2016b, 2016c, 2016a). The effects of the home environment and parenting on early childhood development are partly due to the teaching and learning of special skills. However, the learning opportunities available in HLE suggest that their effects are related to more general aspects of motivation than child development (eg, learning to learn).

Every child has a different pattern of development and growth. The age and development of early childhood can also differentiate the effectiveness of parenting practices and HLE activities given to early childhood. These activities that can contribute to early childhood learning at age three (Dimosthenous et al., 2020). Likewise, with the interests of the children, every child has different benefits and desires. Parents can take advantage of experiences and conversations that such as identification of colors, build skills, shapes, counting, sound-letters, and print concepts. They must have expertise and competences in creating learning opportunities and trusting their ability to teach their children (Bojczyk et al., 2018).

Early childhood is a child who likes to play; everything such as developmental stimulation for children is given by playing. Similarly, the provision of HLE is made by playing while learning. Home Learning Environment provided by parents includes parentschildren interaction in providing affection, security, encouragement, conversation, and positive role models in helping children develop. It also includes various parents-children interactions, learning and playing activities, active activities (playing and reading together), children's events (dancing, painting, reading), parents-children sharing activities (participating in activities), and also learning support parents. According to Lehrl, Evangelou, et al., (2020), the Home Learning Environment (HLE) has three features in assisting the development of children's education at home; these features include the participation of children in the availability of learning materials, learning activities and the quality of parents-children interaction. Parents who have given positive HLE in the early years of their childhood are more likely to offer a stimulating home learning environment $\mathrm{s}$ early childhood grows into adulthood (Lehrl, Evangelou, et al., (2020).

Playing is the children's main activity, creativity, a way to develop reading skills, imagination that lead to different thoughts and empathy, and problem solving skills. Parents who invite children to play fantasy games are associated with an increase in receptive language at the preschool age of children. Parents who can understand the importance of play activities tend to have positive benefits for children's readiness before entering formal school (Alves et al., 2017). The child's daily play experiences at home are an integral part of early childhood mental development to form relationships with other people and the environment around them. When early childhood can describe, understand, and participate in social interactions such as problem solving activities and practices. This will make children successful in literacy and numeracy. Family practice is a source of meaning to provide opportunities for early childhood to learn, gain understanding, have numeracy and literacy skills (Niklas, Cohrssen, et al., 2016b, 2016c, 2016a). 
The frequency of parents in reading for children, reading at home, library visits, and several books at home predicts the child's reading abilities later. Besides, the literacy habits can predict the quality of early childhood literacy competencies. The characteristics of the home environment that support children's literacy competencies represent the construct of a home literacy environment. Books function as cognitive stimulating ingredients. Vocabulary abilities in children can predict the ability to read words at the end of the first year of school and reading comprehension in those years. However, the acquisition of vocabulary from books requires intensive support from parents, and learning is facilitated by social interactions that occur around them (Niklas, Cohrssen, et al., 2016b, 2016c, 2016a).

Parents play an essential role in supporting each child's learning process. Activities given by parents cannot just run without supporting factors in creating HLE. Motivation at the beginning is also recommended because if parents provide motivation, this will make children more confident. The action or game given must also be exciting for him and adjusted to his abilities. In addition, the amount of time given by parents is significant in supporting children. Even though they are busy, parents need to give their best time so that parents can directly monitor the child's development. According to Lehrl, Evangelou, et al. (2020), Children's participation in learning activities and the quality of parent-child interactions are three main characteristics that can support early childhood development. Participation in learning activities has a function to encourage the growth and development of children's vocabulary. Early childhood involvement in reading books is related to phonemic awareness, narrative construction, skills in vocabulary, knowledge concepts, and positive attitudes towards literacy. Likewise, math learning activities at home (such as playing board and counting) are linked to early math skills (Tamis-LeMonda et al., 2019). Parents' involvement in early childhood learning activities in kindergarten is more than when children reach primary education. Some parents try to provide adequate time for their children, but what must be remembered is the consistency of the availability of time to provide learning activities at home (Dimosthenous et al., 2020). The quality of parental involvement with children is the basis of early childhood cognitive and language development (Tamis-LeMonda et al., 2019).

First, concerning the short-term and longterm effects of HLE on early childhood mathematics achievement, the main results obtained from this study indicate the importance of home learning materials. The aspects contained in the learning material were found to be related to children's achievement in mathematics regardless of the first 3 years of the child's age. These findings reveal that home learning activities provided by parents are appropriate for early childhood learning in a shorter period. However, the long-term effect of HLE on mathematics achievement after three years of childhood was considered statistically insignificant (Dimosthenous et al., 2020). The fact can be attributed to the measurement of HLE regarding its stability over time. HLE consists of several aspects, including the provision of learning materials at home and parent-child activities. Some aspects appear to be more stable because they have not changed much (i.e., learning materials at home) (Dimosthenous et al., 2020).

Early childhood learning motivation in classroom-based settings is very important because early childhood education emphasizes the importance of a child-centered approach (Choi \& Cho, 2020). Children's learning motivation shows an influence on the home learning environment. Generally, parents offer different types and levels of thought and encourage a home environment for their children. Supporting the quality and quantity of stimulation in several variations can affect the motivation to learn early childhood in some variations that can affect their learning motivation. Research reveals that children who have a learning opportunity are intrinsically motivated academically. In short, children coming from home environments with more opportunities for development and stimulation have greater motivation (Choi \& Cho, 2020). 


\section{CONCLUSIONS}

The role of parents in shaping HLE is by introducing new learning materials into the home through activities (playing, chatting and reading), offering various learning opportunities and providing fun learning experiences, preparing HLE according to children's needs and interests. Before going any further in building HLE, parents need to understand the extent of the child's ability to provide or create HLE, so that this will affect its provision. Parents need to learn about age-appropriate preschool behavior, discipline strategies, relevant games, materials, and readiness for activities. Parents as primary caregivers must have the motivation, skills and knowledge to involve learning opportunities at home long before they arrive at formal school.

\section{ACKNOWLEDGMENTS}

I would like to thank all the preschoolers and parents in Trucuk District, Klaten Regency for their participation in this research. This research is one requirements in undergoing postgraduate study, I would like to thank Dr. Drs. Sugito., M.A. for his guidance so far. Hopefully this research can provide benefits to institutions and society.

\section{REFERENCES}

Alves, A. F., Gomes, C. M. A., Martins, A., \& Almeida, L. da S. (2017). Cognitive performance and academic achievement: How do family and school converge? European Journal of Education and Psychology, 10(2), 49-56. https:// doi.org/10.1016/j.ejeps.2017.07.001

Anum, A., \& Apriyanto, S. (2019). Detecting Gender'S Strategies in Learning Speaking. Premise: Journal of English Education, 8(1), 57. https://doi.org/10.24127/pj.v8i1.1932

Apriyanto, S., \& Anum, A. (2018). Gender Dynamics on Speaking Interaction in the College Classroom. Jurnal Smart, 4(2), 73. https:// doi.org/10.26638/js.692.203x

Arigusman, A. (2017). Indonesian EFL Learners' perceptions of Classroom Learning Environments in An EFL Context. ASIAN TEFL, 2(2), 103-117.

Biedinger, N. (2011). The Influence of Education and Home Environment on the Cognitive Outcomes of Preschool Children in Germany. Child Development Research, 2011, 1-10. https://doi.org/10.1155/2011/916303

Bojczyk, K. E., Haverback, H. R., \& Pae, H. K. (2018). Investigating Maternal Self-Efficacy and Home Learning Environment of Families Enrolled in Head Start. Early Childhood Education Journal, 46(2), 169-178. https://doi.org/10.1007/s10643-017-0853-y

Choi, N., \& Cho, H. J. (2020). Temperament and Home Environment Characteristics as Predictors of Young Children's Learning Motivation. Early Childhood Education Journal, 48(5), 607-620. https:/ / doi.org/10.1007/s10643-020-01019-7

Creswell, J. W. (2007). Chapter 3: Designing a Qualitative Study. Qualitative Inquiry and Research Design: Choosing among Five Approaches, 35-41. https://doi.org/10.1080/0957514810010204

Dimosthenous, A., Kyriakides, L., \& Panayiotou, A. (2020). Short- and long-term effects of the home learning environment and teachers on student achievement in mathematics: a longitudinal study. School Effectiveness and School Improvement, 31(1), 50-79. https:/ / doi.org/10.1080/09243453.2019.1642212

Flick, U. (2014). The SAGE handbook of qualitative data analysis. In Katie Metzle (Ed.), The SAGE Handbook. SAGE Publication. https://doi.org/10.4135/9781446282243.n33

Hall, J., Sammons, P., Smees, R., Sylva, K., Evangelou, M., Goff, J., Smith, T., \& Smith, G. (2019). Relationships between families' use of Sure Start Children's Centres, changes in home learning environments, and preschool behavioural disorders. Oxford Review of Education, 45(3), 367-389. https:/ / doi.org/10.1080/03054985.2018.1551195

Hatch, J. A. (2002). Doing Qualitative Research in Education Settings. State University of New York Press. 
Holloway, I., \& Wheeler, S. (2010). Qualitative research in nursing and healthcare (Third Edit). Willey-Blackwell. https://doi.org/10.1017/CBO9781107415324.004

Kluczniok, K. (2017). Early Family Risk Factors and Home Learning Environment as Predictors of Children's Early Numeracy Skills Through Preschool. SAGE Open, 7(2). https:/ / doi.org/10.1177/2158244017702197

Kluczniok, K., Lehrl, S., Kuger, S., \& Rossbach, H. G. (2013). Quality of the home learning environment during preschool age - Domains and contextual conditions. European Early Childhood Education Research Journal, 21(3), 420-438. https:// doi.org/10.1080/1350293X.2013.814356

Lehrl, S., Ebert, S., Blaurock, S., Rossbach, H. G., \& Weinert, S. (2020). Long-term and domain-specific relations between the early years home learning environment and students' academic outcomes in secondary school. School Effectiveness and School Improvement, 31(1), 102-124. https:// doi.org/10.1080/09243453.2019.1618346

Lehrl, S., Evangelou, M., \& Sammons, P. (2020). The home learning environment and its role in shaping children's educational development. School Effectiveness and School Improvement, 31(1), 1-6. https:/ / doi.org/10.1080/09243453.2020.1693487

Linberg, A., Lehrl, S., \& Weinert, S. (2020). The Early Years Home Learning Environment Associations With Parent-Child-Course Attendance and Children's Vocabulary at Age 3. Frontiers in Psychology, 11. https://doi.org/10.3389/fpsyg.2020.01425

Miles, M. B., \& Huberman, A. M. (1994). Qualitative data analysis. In Sage. https:// doi.org/10.1136/ebnurs.2011.100352

Miles, M., Huberman, M., \& Saldana, J. (2014). Qualitative Data Analysis (H. Salmon (ed.); 3rd ed.). SAGE Publication. https:// doi.org/10.1080/0140528790010406

Moen, K., \& Middelthon, A. L. (2015). Qualitative Research Methods. In Research in Medical and Biological Sciences: From Planning and Preparation to Grant Application and Publication (pp. 321-378). Elsevier Ltd. https://doi.org/10.1016/B978-0-12-7999432.00010-0

Murphy, M. C. (2020). Bronfenbrenner's bio-ecological model: a theoretical framework to explore the forest school approach? Journal of Outdoor and Environmental Education, 23(2), 191-205. https:/ / doi.org/10.1007/ s42322-020-00056-5

Nielsen, M. W. (2015). New and Persistent Gender Equality Challenges in Academia.

Niklas, F., Cohrssen, C., \& Tayler, C. (2016a). Home Learning Environment and Concept Formation: A Family Intervention Study with Kindergarten Children. Early Childhood Education Journal, 44(5), 419-427. https:// doi.org/10.1007/s10643-015-0726-1

Niklas, F., Cohrssen, C., \& Tayler, C. (2016b). Parents supporting learning: a non-intensive intervention supporting literacy and numeracy in the home learning environment. International Journal of Early Years Education, 24(2), 121-142. https:/ / doi.org/10.1080/09669760.2016.1155147

Niklas, F., Cohrssen, C., \& Tayler, C. (2016c). The Sooner, the Better: Early Reading to Children. SAGE Open, 6(4). https://doi.org/10.1177/2158244016672715

Niklas, F., Nguyen, C., Cloney, D. S., Tayler, C., \& Adams, R. (2016). Self-report measures of the home learning environment in large scale research: Measurement properties and associations with key developmental outcomes. Learning Environments Research, 19(2), 181-202. https://doi.org/10.1007/s10984-016-9206-9

Romo, R. (2015). BUILDING SELF THROUGH FOREIGN LANGUAGE LEARNING : A case study of four adult language learners 'emerging identities. October.

Sammons, P., Toth, K., Sylva, K., Melhuish, E., Siraj, I., \& Taggart, B. (2015). The long-term role of the home learning environment in shaping students' academic attainment in secondary school. Journal of Children's Services, 10(3), 189-201. https:// doi.org/10.1108/JCS-02-2015-0007

Santoso, D., \& Apriyanto, S. (2020). Intercultural Communication and Business Chain Formation of America and Japan. 12(2), 2042-2052. 
DOI: 10.31004/obsesi.vxix.xxx

Schmiedeler, S., Niklas, F., \& Schneider, W. (2014). Symptoms of attention-deficit hyperactivity disorder (ADHD) and home learning environment (HLE): findings from a longitudinal study. European Journal of Psychology of Education, 29(3), 467-482. https://doi.org/10.1007/s10212-013-0208-z

Sénéchal, M., \& Lefevre, J. A. (2014). Continuity and change in the home literacy environment as predictors of growth in vocabulary and reading. Child Development, 85(4), 1552-1568. https:// doi.org/10.1111/cdev.12222

Skwarchuk, S. L., Sowinski, C., \& LeFevre, J. A. (2014). Formal and informal home learning activities in relation to children's early numeracy and literacy skills: The development of a home numeracy model. Journal of Experimental Child Psychology, 121(1), 63-84. https://doi.org/10.1016/j.jecp.2013.11.006

Soto-Calvo, E., Simmons, F. R., Adams, A. M., Francis, H. N., Patel, H., \& Giofrè, D. (2020). Identifying the preschool home learning experiences that predict early number skills: Evidence from a longitudinal study. Early Childhood Research Quarterly, 53, 314-328. https://doi.org/10.1016/j.ecresq.2020.04.004

Tamis-LeMonda, C. S., Luo, R., McFadden, K. E., Bandel, E. T., \& Vallotton, C. (2019). Early home learning environment predicts children's 5th grade academic skills. Applied Developmental Science, 23(2), 153-169. https:// doi.org/10.1080/10888691.2017.1345634

Toth, K., Sammons, P., Sylva, K., Melhuish, E., Siraj, I., \& Taggart, B. (2020). Home learning environment across time: the role of early years HLE and background in predicting HLE at later ages. School Effectiveness and School Improvement, 31(1), 7-30. https:/ / doi.org/10.1080/09243453.2019.1618348

Williamson, K. (2018). Populations and samples. In Research Methods (Second, pp. 359-378). Elsevier Ltd. https://doi.org/10.1016/B978-0-08-102220-7.00015-7

Zhang, S. Z., Inoue, T., Shu, H., \& Georgiou, G. K. (2020). How does home literacy environment influence reading comprehension in Chinese? Evidence from a 3-year longitudinal study. Reading and Writing, 33(7), 1745-1767. https://doi.org/10.1007/s11145-019-09991-2 